\title{
STATING THE CASE OF PAGANISM IN 384 AD -
}

\section{ARGUMENTATION IN THE THIRD RELATIO OF SYMMACHUS}

\section{A.V. van Stekelenburg, University of Stellenbosch}

No other document so clearly and dramatically illustrates the death throes of Roman paganism in its struggle against Christianity than do three letters addressed to the young Emperor Valentinian II in the year $384 \mathrm{AD}$. These letters are the third relatio (official report) by the City Prefect of Rome, Quintus Aurelius Symmachus, and the reactions to its contents contained in two letters (epp. 17 and 18) of the Bishop of Milan, (Saint) Ambrose, addressed to that same Prince.

These three documents deal with several questions regarding the position of traditional pagan worship, which had since the days of Constantine more than half a century earlier, but especially in recent years, become subjected to a number of severe restrictions through imperial legislation. 1

The relatio of Symmachus asked, on behalf of the pagan majority in the Senate, for the rescission of some of these recent anti-pagan decrees. Ambrose vehemently, and successfully, opposed those requests in his two letters. Together the three documents give us a condensed but penetrating view of the dialectics of the two sides in this period of transition that changed Western civilization forever.

In the following we intend to look at the way in which Symmachus stated the case of paganism in his relatio. In the past his argumentation has been called "weak" especially from a theological point of view (Bloch 1971:150 and 156; Klein 1971:164). We wish to see if we can discern the method of Symmachus' arguments and whether they could have been different and more effective. First, however, we will give some more factual information concerning the events that gave rise to the dispute.

The conflict between Symmachus and Ambrose is often referred to as the Ara Victoriae Affair, because one of the requests of the pagans whom Symmachus represented, was that the altar in front of the statue of Victoria in the Senate House should be replaced.2 This altar had been removed by Valentinian's half-brother and co-emperor Gratian, a fervent Christian. The Victoria statue had had a place in the Senate House since the days of Augustus and it was on its altar that the senators had traditionally sworn their oaths.

Gratian had not been the first to remove the altar which was a thorn in the flesh of Christian senators, though these were still in the minority. Constantius II, when visiting the city in 357 , had on that occasion already ordered its removal. Julian the Apostate had it brought back in 361 and it had been left in peace by Valentinian I (364-375), the father of Gratian and Valentinian II. But then Gratian had the altar removed once more in 382 . An embassy led by Symmachus to have the order revoked had been refused audience (Symmachus, relatio 3,1; pseudo-Prosper, De promissis Dei 3,38).

I Codex Theod. 16.10.1-8; see esp. K.L. Noetlichs (1971), Die gesetzgeberischen Massnahmen der christlichen Kaiser des 4. Jahrhunderts gegen Häretiker, Heiden und Juden, Diss. Köln.

2 Ch. 4-6; the statue, the altar, their history and the conflicts in which they played a rôle have been the subject of much research, esp. Wytzes (1977), Klein (1972), Pohlsander (1969) and Sheridan (1966). 
The next year, however, Gratian was killed and in 384 the circumstances for a new attempt to have the altar restored were very promising. Not only was the surviving emperor very young, only 13 years old, but also were many in his entourage in Milan, where the Court resided, non-Christians, most important among them the comites Bauto and Rumoridus, the latter "addicted to the worship of the gentile nations from the first days of boyhood", as Ambrose would remark years later when recalling the affair (ep. 57.3).

The return of the Victoria altar was not the only request by Symmachus. Others concerned the restoration of endowments, immunities, and the right of succession to the Vestal Virgins and other colleges of priests, which had been taken away by Gratian (ch. 11-14; Wytzes 1977:283ff.; Klein 1972:178 note 14).

Apart from all these requests, however, the relatio carried a much more general plea in which the specific ones were incorporated. It is summed up in one sentence in the third chapter: repetimus igitur religionum statum qui reipublicae diu profuit.

Symmachus' wording here is extremely diplomatic. It is obvious that "the state of religious affairs which was so long advantageous to the staten refers primarily to the religious practices of the pagan past. Symmachus, however, does not say so. Irstead, by equating this state of religious affairs with the well-being of the Empire, he appeals to the emperor's sense of duty towards the State.

Immediately afterwards Symmachus tries to convince the young emperor that by adopting anti-pagan measures he would actually go against established imperial policy. Among the emperor's immediate predecessors, he says (ch. 3), there had been an adherent of the ancient faith (Julian) and one who had allowed it to be practiced (Valentinian 1). The emperors whose anti-pagan measures had been the cause of the pagans' problems, Constantius and Gratian, are, of course, omitted. Elsewhere Symmachus tries to blunt the edge of their acts by presenting the first removal of the altar by Constantius as a mistake which was rightfully corrected by his successors (ch. 5 and 7) and Gratian's attitude as the result of the influence of "wicked men" (improbi; ch. 1).

Such cautious efforts to represent anti-pagan measures as going against the interests of the state and time-honoured policy, form a major part of Symmachus' argument. He himself is just as careful to refrain from direct attacks on Christianity. His circumspection in this regard is, of course, influenced by the fact that in his position as Praefectus Urbi appointed by the Crown (praefectus vester) he is addressing a Christian emperor. In these circumstances - and apart from tactical reasons - it was unthinkable that Symmachus would aggressively state his own case or attack his emperor's religion. As he himself says he is offering prayers, not conflict: preces non certamina offerimus (10).

Ambrose was in a different position, though his bullying attitude, especially in his first letter to Valentinian (ep. 17), is unprecedented. He tells the young emperor that his youth will not be accepted as an excuse if he fails to repulse the heathens (ch. 6 and 15) and he openly threatens him with excommunication (13f.). Ambrose's attitude, then and on later occasions, 3 is an early intimation of the struggles between Church and State which lay ahead.

As a fellow-Christian and bishop, and with regard to the basic tenets of Christianity, Ambrose was on safe ground when he began his counter-attack delineating the limitations within which the emperor should react to the requests of the pagans: "as a soldier for

3 For instance in his clashes with Theodosius on the destruction by Christians of a synagogue (ep. 40) and on the massacre in Thessalonica for which he forced the ercperor to do penance (ep. 51 ; de obitu Theodosii oratio, 34). 
Almighty God and our holy faith" while remembering that "the Christian God is the only God. The gods of the heathens are devils" (17.1).4

When Symmachus was composing his missive he knew of course that Ambrose would intervene, as he had done two years earlier with Gratian. Therefore it was of the utmost importance to give as little provocation as possible that could elicit damaging attacks on traditional religion. The religious arguments of the Christians against pagan beliefs and practices must have been known to the City Prefect. For centuries Christian detractors of paganism had harped on the inconsistencies of the many gods, the worship of lifeless images, the goriness of sacrifices, the immorality of rites, etc., just as pagans had attacked what they considered ridiculous and contrary to reason in Christianity. In Rome the two worlds mixed freely and seemingly without personal animosity, 5 but undoubtedly well aware of where they differed and what the other side thought about them, as the numerous apologetic and invective works prove. 6 The same arguments used in those works will have occurred in discussions at a personal level, the frequency and intensity of which we can only guess.

Symmachus' strategy therefore is not to attack Christianity. Instead he tries to establish common ground and purpose for Christianity and paganism and then proceeds to plead tolerance for the latter on the ground of this commonality and because of the proven merits of the old religion for the Roman State.

It was not difficult to at least suggest some common ground. Hellenistic-Roman thinking had already before the birth of Christ developed monistic-looking concepts especially through Stoicism. In the fourth century Neoplatonic reasoning looked upon the many individual gods as emanations of one Summus Deus (ró $e ́ v$ ) who was often equated with the Sun (Wytzes 1977:48ff.). From the Summus Deus originated the Divina Mens (vovs) which had created the cosmos.

Non-Christian theological thinking in Symmachus' time was greatly influenced by Neoplatonic theories (Wytzes 1977:50ff.). Symmachus is therefore only expounding current opinion when he states that it is reasonable to consider the object of all worship one: aequum est quidquid omnes colunt, unum putari (10). What difference does it make by what pains each seeks the truth? We cannot attain to so great a secret by one road: quid interest qua quisque prudentia verum requiran? uno itinere non potest perveniri ad tam grande secretum (ibid.). Oaths, he says, are an effective deterrent, because no place is safe for the perjured as all things are filled with God: omnia quidem Deo plena sunt (6).

The purpose of this careful use of Neoplatonic idiom is of course to obfuscate the differences between the religions. Certainly for a thirteen year old the result might be that

4 Ambrose was convinced of the baselessness of any discussion between the two religions and often emphasised the unique source of Christianity's claim to be the only true religion, f.i. de bono mortis 11,51: nos divini praecepti auctoritatem habemus (we possess the authority of God's command); cf. ep. 18.8: et quod wos suspicionibus quaeritis, nos ex ipsa sapientia Dei et veritate compertum habemus (and what you seek by fancies, we have found out from the very Wisdom and Truth of God).

5 Symmachus and Ambrose even exchanged letters, though religion did not enter into the correspondence that has survived; Symmachus, epp. 3.30-37.

6 For instance Prudentius" "Contra Symmachum" in which the battle of the Ara Victoriae was fought once more and which was written approximately $402 \mathrm{AD}$ at the end of Symmachus' life. It was clearly intended to be read not only by Christians, but also by pagans; T.D. Barnes (1976), Prudentius' Contra Symmachum, American Journal of Philology 97, 377. 
the gap between monotheism and polytheism began looking deceptively narrow. Ambrose therefore warns the young emperor from the start: "They (the heathens) sound weighty and grand, but they defend what has no capacity for truth. They speak of God but worship idols" (18.2).

Ambrose here puts his finger directly on what tends to striks us too as a contradiction between theory and practice among the last pagans of Rome. Next to their intellectual and lofty theories about the one-ness of all divinity stood an astonishing preoccupation with a whole array of individual gods. 7 Symmachus still refers to this pantheon as dii patrii and dii indigetes (10) and to their cults as the caeremonia avita (9), but they now included much that was certainly not indigenous, and foreign practices which their Republican forefathers would have been ashamed to admit to.

We may take the information contained in a well-known funeral inscriptions of one of Symmachus' close friends as an example. The deceased in question is the former Praefectus Urbi Vettius Agorius Praetextatus, whose death later in 384 would be a reason for Symmachus to ask the emperor to be released from his office (relatio 10). In this inscription Praetextatus is named augur, priest of Vesta and of Sol, and initiate in the mysteries of Dionysus, Ceres and Mithras. As a tauroboliatus in the last cult he must have undergone the gory ritual of bathing in the blood of a bull. He is also praised for having introduced his wife into the mystery cults of Cybele and Hecate.

It is unlikely that Symmachus' zeal in the practice of worship came second to that of Praetextatus. In two of his letters he actually berates his friend for negligence in his pontifical duties! 9 But of course those daily aspects of pagan religion could have no place in his relatio. In fact, apart from Victoria, not a single individual god is mentioned. And as to Victoria, she is rather to be venerated as a power (potentia) than as a goddess. "Let at least that honour be paid to the name which is refused to the goddess" (reddatur tamen saltem nomini honor, qui numini denegatus est (4).

When the collective gods are mentioned it is almost always with reference to their function as protectors of Rome. In line with Neoplatonic thought Symmachus states that the Divine Mind has distributed different guardians and cults to different cities. Knowledge of the gods (cognitio numinum) comes to us from the documented evidence of the prosperity of the past. Therefore we ought to follow our ancestors if we want to secure that same prosperity for the future (8). As proof of what disasters will befall the state if the gods are neglected or insulted Symmachus describes dramatically and in epic terms the effects of the famine of the previous year, which he ascribes to Gratian's abolishment of the privileges of the Vestal Virgins and other ministers (14-15).

Ambrose's answer is sarcasm: why did the gods wait so long to defeat Hannibal if they were on the Romans' side all the time? (18.4); and did Hannibal not worship those same

7 "a follower of 300,000 gods" (amans ter centum milia divum) Prudentius would scoff, with reference to the pagan emperor and philosopher Julian the Apostate (Apotheosis 453).

CIL VI 1779; P. Lambrechts (1955), Op de grens van heidendom en Christendom. Het grafschrifi van Vettius Agorius Praetexatus en Fabia Aconia Paulina, Mededelingen van de Koninklijke Akademie van Wetenschappen XVII, Brussel, 1955; Wytzes, (1977), $138 f f$.

9 epp. 1.47 and 1.51; Wytzes, (1977) 62f. Symmachus' interest in Oriental religions has been doubted because of his reticence on this subject; F. Paschoud (1965), Historia 14, 215-235. It is, however, more likely that in this aspect he differed, if at all, only in degree from Praetextatus and others; J.F. Matthews (1973), Symmachus and the oriental cults, IRS LXIII, 173-195; Wytzes, (1977), $121 \mathrm{ff}$. 
gods? (18.5); had the emperor Valerian, who died a slave of the Parthian King, perhaps been a Christian?; was there no altar of Victoria then? (18.7); and surely the famine of the previous year had been the first ever in the history of mankind (18.17-18)?

The argument that heavenly support for the State and its citizens depends on giving due reverence to the divine power(s) and the observance of the correct rites is of course shared by many religions. In Roman tradition the fear of breaking the pax deorum had always been strong and Symmachus refers to it when he says: diis ... pacem rogamus (10). Ambrose expresses the Christian variety of this fear, that salvation is not sure unless everyone sincerely worships the true God of the Christians: aliter enim salus tuta esse non poterit, nisi unusquisque Deum verum, hoc est Deum christianorum, ... veraciter colat (17.1).

Between the two claims, of maintaining on the one side the pax deorwm and on the other the pax Dei, there existed for Christians on theological grounds no possibility of a compromise. That is the meaning of the opening lines of Ambrose's 17th letter, written even before he had set eyes on Symmachus' relatio. But how many of the high-ranking Christian officials at the Court of Valentinian would have shared the bishop's uncompromising attitude? Ambrose himself in his consolation speech on the death of Valentinian in 392 states that shortly before his death all the emperor's advisers, both pagans and Christians, had advised him to yield to the request of the heathens, which had once more been presented to him. Valentinian, according to Ambrose (he may have been exaggerating for rhetorical effect) opposed them alone "like a Daniel".10

Surely on that occasion those Christian advisers were not swayed by the theological arguments contained in the pagans' plea, but by political expediency and religious indifference. After all, this was still an era in which the religious identity of many new Christians was fluid and their susceptibility to arguments of traditional values still strong enough for them to be induced to heed their call if the political situation of the day warranted it.11 The days of Valentinian I and Valens during which an attitude of religious tolerance had existed, were still too recent that they could not be recalled.

Symmachus' relatio should therefore not be judged too much on its theological contents. It must rather be considered an emphatic declaration by the Senate of Rome that it still felt strongly about its traditional religion. The implication was, of course, that the senators would give their support - for whatever it was worth in those times 12 - more readily to an emperor who heeded their request, as would happen in 392 when Eugenius gave in to their petitions. 13

The relatio was never meant to be a refutation of Christianity like Celsus " True Account against the Christians". That would have been counterproductive. Symmachus clearly shied away from confrontation and from anything that might provoke the usual kind of sarcastic counter-attack which his carefully worded missive nevertheless received from Ambrose.

10 De obitu Valentiniani consolatio, 19, 20; 52.

11 On the preservation of pagan traditions and rites, such as the Lupercalia, by an increasingly Christian nobility in these and later times, see P. Brown (1972), Religion and society in the age of Saint Augustine, London, $161 \mathrm{ff}$. The 4th century catacombs on the Via Latina, discovered in 1956, show examples of scenes from the Bible and from pagan mythology side by side.

12 "When compared with their self-assertion ... the political power of the senators was minimal"; J. Vogt (1967), The decline of Rome, London, 143.

13 Ambrosius ep. 57.6; see Bloch (1971), 162ff. on this episode. 
The City Prefect must have known such attacks from personal experience in word or in writing.

He must also have realised that his faction's humanist tolerance in religious affairs would never be reciprocated by Christianity, which was by definition intolerant of any other religion. Between the "many ways" of enlightened paganism and the "one way" of dogmatic Christianity there was no real possibility of compromise.

All that Symmachus and his friends could hope for was that the repeated presentation of their case - in 382 , in 384 and after 384 on at least three more occasions: to Theodosius (between 389 and 391), once more to Valentinian (early 392) and to the usurper Eugenius (392)14 - might coincide with political considerations at the Court which favoured the granting of their request.

Such considerations almost won the day early in 392, when Valentinian was still emperor but virtually held at ransom by his magister militwm Arbogast in Gaul. There was good reason to speculate that in this situation he would like to court the aristocrats of Rome for their support and would therefore grant their repeated request. His councillors in any case clearly advised him to do so, even the Christians among them, as Ambrose knew.15 After Valentinian's death (by suicide or murder) shortly afterwards the request was at last favourably received by the usurper Eugenius after he had decided to gain the support of the senate against Theodosius.

Everything depended therefore on the right political conditions. In the year $384 \mathrm{AD}$ the senators may have misinterpreted an earlier concession allowing the City Prefect to reclaim spoils taken by private persons from public buildings such as temples. 16 They may have thought this concession, and coincidental factors such as the youth of the emperor and the presence of influential pagans at his court, made the prospects for a petition good. Symmachus was once more asked to draw up the missive, which he did skilfully though of necessity realizing that it would not be judged so much on its merits as on political expediency. The product is nevertheless an elegant piece of rhetoric with a clever use of semantics. Enlightened egalitarian phrases about religion in general combine with historically accepted appeals on maintaining ancestral values, whose proven merits imply their usefulness for the future.

That Symmachus was not successful was not because of weaknesses in his argumentation, theological or otherwise, but because of prevailing political opinion at the court. Ambrose, the one person who may have tipped this opinion against the granting of the request, seems, however, to have immediately understood the reality of the danger as soon as he heard of the arrival of the missive.

The haste and vehemence of his first letter (ep. 17), written before he had even had an opportunity to read the relatio, shows that he took the challenge anything but lightly. The political implications of excommunication with which he threatened the young emperor will have weighed more heavily than all the counter-arguments and invective he heaped upon paganism.

\footnotetext{
14 Ambrose mentions these three later occurrences in ep. 57.4-6.

15 De obitu Valentiniani consolatio, 19. 


\section{BIBLIOGRAPHY}

Bloch, H. 1971. Ein neues inschriftliches Zeugnis der letzten Erlebung des Heidentums in Westrom 339/394 n.Chr., in Das frahe Christentum im Romischen Staat. Darmstadt.

Klein, R. 1971. Symmachus, eine tragische Gestalt des ausgehenden Heidentums. Darmstadt.

Klein, R. 1972. Der Streit un den Victoriaaltar. Darmstadt.

Pohlsander, H.A. 1969. "Victory. The story of a statue." Historia 18, 588-597.

Sheridan, J.J. 1966. "The altar of Victory - Paganism's last battle." L'Antiquité Classique $35,188-206$.

Wytzes, J. 1977. Der letzte Kampf des Heidentums in Rom. Leiden. 